\title{
Neurometabolic indicators of mitochondrial dysfunction in repetitive mild traumatic brain injury
}

\author{
Susan Kim ${ }^{\ddagger}$, Steve C Han*, ${ }^{*}$, , Alexander J Gallan² \& Jasmeet P Hayes ${ }^{3,4}$ \\ ${ }^{1}$ Boston University School of Medicine, Boston, MA 02118, USA \\ ${ }^{2}$ Department of Pathology, University of Chicago Medical Center, Chicago, IL 60637, USA \\ ${ }^{3}$ National Center for PTSD, VA Boston Healthcare System, Jamaica Plain, MA 02130, USA \\ ${ }^{4}$ Department of Psychiatry, Boston University School of Medicine, Boston, MA 02118, USA \\ * Author for correspondence: Tel.: +1 714681 6802; shan1@bu.edu \\ $\ddagger$ Authors contributed equally
}

Mild traumatic brain injury (mTBI) is a significant national health concern and there is growing evidence that repetitive $\mathrm{mTBI}$ (rmTBI) can cause long-term change in brain structure and function. The mitochondrion has been suggested to be involved in the mechanism of TBI. There are noninvasive methods of determining mitochondrial dysfunction through biomarkers and spectroscopy. Mitochondrial dysfunction has been implicated in a variety of neurological consequences secondary to rmTBI through activation of caspases and calpains. The purpose of this review is to examine the mechanism of mitochondrial dysfunction in rmTBI and its downstream effects on neuronal cell death, axonal injury and blood-brain barrier compromise.

First draft submitted: 23 May 2017; Accepted for publication: 17 July 2017; Published online: 4 October 2017

Keywords: axonal injury $\bullet$ biomarkers $\bullet$ blood-brain barrier $\bullet$ mitochondrial dysfunction $\bullet$ mTBI $\bullet$ rmTBI $\bullet$ TBI

Mild traumatic brain injury (mTBI) is a significant national health concern that accounts for up to $75 \%$ of the 1.5 million TBIs sustained in the USA each year, and costs the taxpayers at least US\$17 billion annually [1]. Clinical symptoms immediately following trauma include lethargy, disorientation, vertigo, headaches, sensitivity to light and sound, among others [2]. $\mathrm{mTBI}$ is diagnosed if post-traumatic amnesia or alteration of consciousness is $\leq 24 \mathrm{~h}$; if the length of loss of consciousness is $\leq 30 \mathrm{~min}$; and/or, if a patient scores 13-15 on the Glasgow Coma Scale [3,4].

Most individuals exposed to mTBI recover to baseline within 3 months [5]. However, there is growing awareness that repetitive mTBI (rmTBI), or even repetitive hits to the head without subsequent symptoms of TBI, are associated with chronic effects on the brain and clinical symptoms [6]. Sports injury studies suggest that receiving several concomitant concussions may lead to either cumulative increases or a prolonging of the symptoms seen in single injuries [7-13]. US military personnel serving in Iraq and Afghanistan may be consistently threatened with multiple low-level blast exposure in and around the theaters of war [14,15]. Moreover, recent work in the area of chronic traumatic encephalopathy indicates that repetitive concussions or mTBI may be linked to chronic traumatic encephalopathy [16-18].

Although the acute and long-term behavioral consequences of rmTBI have gained recent attention from researchers, the media and funding agencies, the underlying molecular mechanisms are still largely unknown. The purpose of this review is to synthesize findings relating to mitochondrial dysfunction following rmTBI and downstream effects including neuronal cell death, axonal injury and blood-brain barrier (BBB) compromise. Relevant animal models and human literature will be explored, as well as key methodology used to study aspects of rmTBI and the various mechanisms of injury (Table 1).

Of note, the definition of the term concussion is in discussion with regard to the clarification of the terminology. It is difficult to distinguish concussion from mTBI as there is no clear distinction in pathological findings, and inciting injuries are biomechanically similar [19]. In addition, concussion and mTBI share many clinical symptoms including headache, cognitive impairment and sleep disturbance. A review even suggests incorporating concussion 
Table 1. Summary of studies and their findings in the review regarding mild traumatic brain injury, repetitive mild traumatic brain injury and mitochondrial dysfunction.

Study (year)

Vagnozzi et al. (2008)

\section{Type of injury}

mTBI and rmTBI, traumatically

induced alteration in mental

status, with clinical symptoms of

concussion, with post injury MRI

negative for intracranial lesion

\section{Subjects information}

11 mTBI human subjects

athletes, ages 21-35; 3

rmTBI human subjects,

ages $25-30$

\section{Method of injury Study findings}

$\mathrm{NAA} / \mathrm{Cr}$ ratio in singly concussed athletes was

lower compared with control subjects at 3 days postinjury and recovered to control values at 30 days postinjury; second injury (which occurred at 10,12 and 13 days from the first one) was associated with a further decrease in $\mathrm{NAA} / \mathrm{Cr}$ levels post second injury with full restoration taking place at 45 days post initial injury
Vagnozzi et al. (2007) rmTBI, drop-weight (450 g at 1-m height) without postinjury skull fracture, seizure, nasal bleeding 42 Wistar male rat subjects Drop-weight weighing $300-350 \mathrm{~g}$, ages not stated or death

ATP, NAA and acetyl-CoA levels were maximally decreased when the interinjury interval was 3 days, even after a 7-day recovery period post second injury; by contrast, rats subjected to an interinjury interval of 5 days did not show differential levels compared with the control group

\section{Prins et al. (2013)}

mTBI and rmTBI, controlled pneumatic piston cylinder injury 36 psi without skull fracture

33 Sprague-Dawley rat Controlled pneumatic subjects weighing $142.9 \pm$ piston cylinder $3.9 \mathrm{~g}$, age 35 days

Rats subjected to a single mTBI show decreased CMRgluc in the parietal cortex and the hippocampus; CMRgluc levels decreased further when rats sustain a second injury within $24 \mathrm{~h}$ of the first injury, and remain decreased 3 days postinjury whereas rats subjected to a single mTBI returned to normal CMRgluc values; in contrast, rats that were subjected to 120-h interval rmTBI showed no significant changes compared with that in the group with single $\mathrm{mTBI}$; the CMRgluc in this rmTBI group returned to the levels seen in the uninjured group 3 days after the second injury

Peskind et al. (2011) rmTBI, at least one blast exposure history that resulted in acute $\mathrm{mTBI}$ according to the ACRM critera except the GCS requirement

\section{2 human subjects Iraq Blast injury}

war veterans, age

$32 \pm 8.5$ years
Subjects with blast-induced rmTBI exhibited decreased CMRgluc compared with control subjects with no history of brain injury; the decrease in CMRgluc appears to be

long-lasting as the average time between the veterans' last blast exposure and the time at which CMRgluc was measured was 3.5 years

Govindaraju et al. (2004) mTBI, injury with GCS $13-15$ and LOC less than 30 min, none with post-traumatic amnesia more 14 human subjects, ages Various (MVA, fall 18-53 years assault)

Decreases in NAA/Cr and NAA/Cho, markers of neuronal damage or disruption, in 14 human subjects with mTBI compared with 13 control subjects when measured within 1 month postinjury

than a few hours

Son et al. (2000)

Lazzarino et al. (2012)

Hinzman et al. (2010)

Amorini AM (2017) mTBI, regional brain contusion with initial GCS 13-15

rmTBI, sport-related concussion inducing a transient alteration in mental status, GCS $14-15$ and normal neurological objective signs

$\mathrm{mTBI}, 1.1 \pm 0.01 \mathrm{~atm}$; moderate TBI $2.0 \pm 0.02 \mathrm{~atm}$

mTBI, weight-drop $450 \mathrm{~g}$ from 1-m height; severe TB weight-drop $450 \mathrm{~g}$ from $2-\mathrm{m}$ height
7 human subjects, ages Various (MVA, fall, $15-60$ years

6 human subjects atheletes, ages 20-33 years assault)

\section{Sports-related} concussion

Reduction in NAA/Cr ratios in pericontusional regions in 7 mTBI human subjects compared with 25 control subjects

Repeat concussion increased the time of recovery of $\mathrm{NAA} / \mathrm{Cr}$ to baseline as well as the persistence of clinical symptoms rats, weighing $350-400 \mathrm{~g}$, ages not stated glutamate levels and the levels correlate with the injury severity

60 male Wistar rats, Drop-weight weighing $300-350 \mathrm{~g}$, ages not stated

mTBI caused modest transient changes in NAA, [39] Asp, GABA, Gly and Arg; severe TBI showed greater, long-lasting changes in Glu, GIn, NAA, Asp, GABA, Ser, Gly, Ala, Citr, Tau, Met, SAH, L-Cystat, Tyr and Phe; severity of injury is a major determinant of processes involving amino acid metabolism

Zander et al. (2016)

mTBI and rmTBI, 10-14 psi pressure measured 2 inches above the culture plates

Primary rat cortical
neurons from $10 \mathrm{E} 18$
$\begin{aligned} & \text { Sprague-Dawley rats, ages } \\ & \text { not stated }\end{aligned}$

Primary rat cortical not stated
Glutamate release from neurons subjected to three blast injuries was significantly greate than those exposed to single or no injuries 
Table 1. Summary of studies and their findings in the review regarding mild traumatic brain injury, repetitive mild traumatic brain injury and mitochondrial dysfunction (cont.).

\begin{tabular}{|c|c|c|c|c|c|}
\hline Study (year) & Type of injury & Subjects information & Method of injury & Study findings & Ref. \\
\hline $\begin{array}{l}\text { Raghavendra Rao et al. } \\
\text { (1998) }\end{array}$ & $\begin{array}{l}\text { TBI type not specified, } 4-\mathrm{mm} \\
\text { diameter tip at velocity of } 3 \mathrm{~m} / \mathrm{s} \\
\text { and 2-mm deformation }\end{array}$ & $\begin{array}{l}\text { Male Sprague-Dawley } \\
\text { rats, weighing } 250-300 \mathrm{~g} \text {, } \\
\text { ages not stated but } \\
\text { reports adult }\end{array}$ & $\begin{array}{l}\text { Injury via controlled } \\
\text { cortical impact device }\end{array}$ & $\begin{array}{l}\text { TBI downregulated proteins of glial glutamate } \\
\text { transporters GLT-1 and GLAST, which are } \\
\text { responsible for clearance of glutamate }\end{array}$ & [42] \\
\hline Sullivan et al. (1999) & $\begin{array}{l}\text { TBI type not specified, } 5-\mathrm{mm} \\
\text { diameter tip at velocity of } 3.5 \\
\mathrm{~m} / \mathrm{s} \text { and to } 2-\mathrm{mm} \text { depth }\end{array}$ & $\begin{array}{l}70 \text { male Sprague-Dawley } \\
\text { rats, weighing } 250-300 \mathrm{~g} \text {, } \\
\text { ages not stated but } \\
\text { reports young adult }\end{array}$ & $\begin{array}{l}\text { Injury via } \\
\text { pneumatically } \\
\text { controlled impacting } \\
\text { device }\end{array}$ & $\begin{array}{l}\text { Postinjury administration of mitochondrial PTP } \\
\text { inhibitor, cyclosporin A, attenuates the } \\
\text { disruption of the mitochondrial membrane } \\
\text { potential and calcium homeostasis }\end{array}$ & [44] \\
\hline Ashwal et al. (2004) & $\begin{array}{l}\text { TBI type not specified, history of } \\
\text { TBI and presumed diffuse axonal } \\
\text { injury }\end{array}$ & $\begin{array}{l}38 \text { children and } \\
\text { adolescents, age range } \\
\text { unspecified }\end{array}$ & $\begin{array}{l}\text { Injury type not } \\
\text { specified }\end{array}$ & $\begin{array}{l}\text { Increased glutamate/glutamine levels and } \\
\text { lower NAA/Cho in children and adolescents } \\
\text { with TBI compared with controls }\end{array}$ & [46] \\
\hline Yeo et al. (2011) & mTBI, based on ACRM criteria & $\begin{array}{l}30 \text { human subjects, age } \\
27.3 \pm 9.52 \text { years }\end{array}$ & $\begin{array}{l}\text { Various (MVA, fall, } \\
\text { assault, collision, sports } \\
\text { injury, falling object) }\end{array}$ & $\begin{array}{l}\text { Increased glutamate/glutamine levels in the } \\
\text { white matter in mTBI human adults when } \\
\text { measured at an average of } 13 \text { days postinjury }\end{array}$ & [47] \\
\hline Okonkwo et al. (1999) & $\begin{array}{l}\text { TBI type not specified, force of } \\
\text { impact device not specified }\end{array}$ & $\begin{array}{l}22 \text { male Sprague-Dawley } \\
\text { rats, weighing } 375-400 \mathrm{~g} \text {, } \\
\text { ages not stated }\end{array}$ & $\begin{array}{l}\text { Impact acceleration } \\
\text { injury }\end{array}$ & $\begin{array}{l}\text { Rats pretreated with cyclosporin A before TBI } \\
\text { showed decreased axonal damage and } \\
\text { exhibited mitochondrial protection compared } \\
\text { with controls }\end{array}$ & [50] \\
\hline Buki et al. (2000) & $\begin{array}{l}\text { TBI type not specified, } \\
\text { drop-weight } 450 \mathrm{~g} \text { from 2-m } \\
\text { height }\end{array}$ & $\begin{array}{l}25 \text { Sprague-Dawley rats, } \\
\text { weighing } 365-398 \mathrm{~g} \text {, ages } \\
\text { not stated }\end{array}$ & Drop-weight & $\begin{array}{l}\text { Single TBI resulted in significant increase in } \\
\text { cytochrome } C \text { release and caspase- } 3 \text { activation } \\
\text { in injured axons; sites of these changes were } \\
\text { associated with mitochondrial swelling }\end{array}$ & [52] \\
\hline Tweedie et al. (2007) & $\begin{array}{l}\mathrm{mTBI} \text {, drop-weight } 30 \text { or } 50 \mathrm{~g} \\
\text { weight from } 80-\mathrm{cm} \text { height }\end{array}$ & $\begin{array}{l}\text { Male ICR mice, weighing } \\
30-40 \mathrm{~g} \text {, ages not stated }\end{array}$ & Drop-weight & $\begin{array}{l}\text { mTBI resulted in decreased levels of } \\
\text { procaspase- } 3 \text { and increased levels of Bax }\end{array}$ & [53] \\
\hline Abdul-Muneer (2013) & $\begin{array}{l}\text { mTBI and rmTBI, } 123 \mathrm{kPa} \\
\text { intensity blast on blast-wave } \\
\text { simulation device }\end{array}$ & $\begin{array}{l}12 \text { male Sprague-Dawley } \\
\text { rats, age } 11 \text { weeks }\end{array}$ & Blast injury & $\begin{array}{l}\text { rmTBI showed greater activation of caspases } \\
\text { compared with single mTBI; mTBI and rmTBI } \\
\text { resulted in increased levels of oxidative } \\
\text { damage markers in the brain microvessels, } \\
\text { increased ROS levels in the brain, and } \\
\text { decreased expression of BBB tight-junction } \\
\text { proteins }\end{array}$ & [54] \\
\hline Huh et al. (2007) & $\begin{array}{l}\text { mTBI and rmTBI, controlled } \\
\text { cortical impact device } 5 \mathrm{~mm} \\
\text { diameter tip at velocity of } 5 \mathrm{~m} / \mathrm{s}\end{array}$ & $\begin{array}{l}48 \text { male and female rat } \\
\text { subjects, age } 11 \text { days }\end{array}$ & $\begin{array}{l}\text { Controlled cortical } \\
\text { impact injury }\end{array}$ & $\begin{array}{l}\text { Calpain activation was seen in axons in } \\
\text { subcortical white matter tracts of rats } \\
\text { subjected to one, two or three mTBls at day } 1 \\
\text { and increased with the number of injuries }\end{array}$ & [57] \\
\hline Arrington et al. (2006) & $\begin{array}{l}\text { Overexpression of Calpain 10, } \\
\text { not injury }\end{array}$ & $\begin{array}{l}\text { Kidney mitochondria } \\
\text { isolated from male } \\
\text { Sprague-Dawley rats } \\
\text { (weighing } 250 \mathrm{~g} \text { ) and } \\
\text { female New Zealand } \\
\text { White rabbits (weighing } 2 \\
\mathrm{~kg} \text { ) }\end{array}$ & $\begin{array}{l}\text { Overexpression of } \\
\text { Calpain 10, not injury }\end{array}$ & $\begin{array}{l}\text { Overexpression of Calpain } 10 \text { resulted in } \\
\text { morphologic signs of mitochondrial } \\
\text { dysfunction; Calpain } 10 \text { targeted parts of the } \\
\text { electron transport chain in the mitochondria } \\
\text { essential for aerobic cellular respiration }\end{array}$ & [60] \\
\hline Raghupathi et al. (2004) & $\begin{array}{l}\text { mTBI and rmTBI, head rotational } \\
\text { acceleration in the axial plane } \\
\text { using the HYGE pneumatic } \\
\text { actuator }\end{array}$ & $\begin{array}{l}11 \text { neonatal farm piglets, } \\
\text { ages } 3-5 \text { days }\end{array}$ & $\begin{array}{l}\text { Rotational acceleration } \\
\text { injury }\end{array}$ & $\begin{array}{l}\text { More regions of axonal damage were seen in } \\
\text { pigs that sustained two mild rotational head } \\
\text { injuries (10-15 min apart) compared with pigs } \\
\text { with single injury }\end{array}$ & [62] \\
\hline Laurer et al. (2001) & $\begin{array}{l}\mathrm{mTBI} \text { and } \mathrm{rmTBI} \text {, controlled } \\
\text { cortical impact devide } 6-\mathrm{mm} \\
\text { diameter tip at velocity } 4.8-5.6 \\
\mathrm{~m} / \mathrm{s}\end{array}$ & $\begin{array}{l}92 \text { male } \mathrm{C} 57 \mathrm{BL} / 6 \text { mice, } \\
\text { ages } 8-10 \text { weeks }\end{array}$ & $\begin{array}{l}\text { Controlled cortical } \\
\text { impact injury }\end{array}$ & $\begin{array}{l}\beta \text {-APP immunoreactivity (an indicator of } \\
\text { traumatic axonal injury) in the brain of rmTBI } \\
\text { mice was markedly elevated compared with } \\
\text { single mTBI mice }\end{array}$ & [63] \\
\hline Shitaka et al. (2011) & $\begin{array}{l}\mathrm{mTBI} \text { and } \mathrm{rmTBI} \text {, electromagnetic } \\
\text { stereotaxic impact device with } \\
\text { 9-mm diameter tip at velocity } 5 \\
\mathrm{~m} / \mathrm{s}\end{array}$ & $\begin{array}{l}147 \text { male } \mathrm{C} 57 \mathrm{BL} / 6 \mathrm{~J} \\
\text { wild-type mice, ages } 2-3 \\
\text { months }\end{array}$ & $\begin{array}{l}\text { Electromagnetic } \\
\text { stereotaxic impact } \\
\text { injury }\end{array}$ & $\begin{array}{l}\text { Greater APP immunoreactivity in rats exposed } \\
\text { to single and two mTBIs }\end{array}$ & [64] \\
\hline Yang MS et al. (1985) & $\begin{array}{l}\text { mTBI, fluid percussion pulse } \\
1.9-2.2 \mathrm{~atm}\end{array}$ & $\begin{array}{l}12 \text { male and female cats, } \\
\text { weighing } 3-4 \mathrm{~kg} \text {, ages not } \\
\text { stated }\end{array}$ & Fluid-percussion injury & $\begin{array}{l}\text { Brain tissue subjected to single mTBI resulted } \\
\text { in increases in markers of impaired } \\
\text { brain/mitochondrial metabolism without } \\
\text { evidence of cerebral ischemia }\end{array}$ & [65] \\
\hline Xing et al. (2013) & $\begin{array}{l}\text { mTBI, fluid percussion pulse } 2.5 \\
\text { atm }\end{array}$ & $\begin{array}{l}38 \text { male Sprague-Dawley } \\
\text { rats, weighing } 175-275 \mathrm{~g} \text {, } \\
\text { ages not stated but } \\
\text { reports adult }\end{array}$ & Fluid-percussion injury & $\begin{array}{l}\text { Brain tissues subjected to single } \mathrm{mTBI} \\
\text { exhibited reduced expression of mitochondrial } \\
\text { proteins involved in the electron transport } \\
\text { chain and pyruvate dehydrogenase }\end{array}$ & [66] \\
\hline
\end{tabular}


Table 1. Summary of studies and their findings in the review regarding mild traumatic brain injury, repetitive mild traumatic brain injury and mitochondrial dysfunction (cont.).

\begin{tabular}{|c|c|c|c|c|c|}
\hline Study (year) & Type of injury & Subjects information & Method of injury & Study findings & Ref. \\
\hline Uryu et al. (2002) & $\begin{array}{l}\mathrm{mTBI} \text { and } \mathrm{rmTBI} \text {, controlled } \\
\text { cortical impact with } 6 \mathrm{~mm} \\
\text { diameter tip at velocity } 4.8-5.6 \\
\mathrm{~m} / \mathrm{s}\end{array}$ & $\begin{array}{l}\text { Tg APP } 695 \text { swe and WT } \\
\text { mice, age } 9 \text { months }\end{array}$ & $\begin{array}{l}\text { Controlled cortical } \\
\text { impact injury }\end{array}$ & $\begin{array}{l}\text { rmTBI, but not single mTBI, increase in Abeta } \\
\text { deposition and levels as well as levels of } \\
\text { isoprostanes, markers of lipid peroxidation }\end{array}$ & [68] \\
\hline Amorini et al. (2016) & $\begin{array}{l}\mathrm{mTBI} \text { and severe } \mathrm{TBI} \\
\text { drop-weight } 450 \mathrm{~g} \text { from } 1 \mathrm{~m} \\
\text { (mTBI) and } 2 \mathrm{~m} \text { (severe } \mathrm{TBI})\end{array}$ & $\begin{array}{l}90 \text { male Wistar rats, } \\
\text { weighing } 300-350 \mathrm{~g} \text {, ages } \\
\text { not stated }\end{array}$ & Drop-weight & $\begin{array}{l}\text { mTBI caused late increase in glycolytic gene } \\
\text { expression and enzymatic activities; severe TBI } \\
\text { resulted in early increase in glycolytic gene } \\
\text { expression and enzymatic activities }\end{array}$ & [67] \\
\hline Slemmer et al. (2002) & $\begin{array}{l}\text { mTBI and rmTBI, stretch injury } \\
\text { using } 94 \mathrm{~A} \text { Cell Injury Controller } \\
\text { with 5.5-mm stretch }\end{array}$ & $\begin{array}{l}\text { Primary hippocampal } \\
\text { cultures prepared from } \\
\text { E18 FVB/N mouse } \\
\text { embryos, cells used for } \\
\text { experiments within } \\
\text { 9-13 days in vitro }\end{array}$ & Stretch injury & $\begin{array}{l}\text { rmTBI and mTBI resulted in elevated levels of } \\
\text { S-100 beta and NSE (markers of CNS damage) } \\
\text { compared with controls; rmTBI caused greater } \\
\text { increase in NSE compared with mTBI } 6 \mathrm{~h} \\
\text { postinjury }\end{array}$ & [69] \\
\hline Slemmer et al. (2004) & $\begin{array}{l}\text { mTBI and moderate TBI, stretch } \\
\text { injury using 94A Cell Injury } \\
\text { Controller with } 5.5 \mathrm{~mm} \text { (mild) } \\
\text { and } 6.5 \mathrm{~mm} \text { (moderate) stretch }\end{array}$ & $\begin{array}{l}\text { Primary cerebellar cultures } \\
\text { prepared from E18 } \\
\text { wild-type FVB/N mouse } \\
\text { embryos }\end{array}$ & Stretch injury & $\begin{array}{l}\text { mTBI and moderate TBI resulted in elevated } \\
\text { levels of S-100 beta and NSE compared with } \\
\text { controls; moderate TBI caused a greater } \\
\text { increase in levels of S-100 beta compared with } \\
\text { mTBI } 24 \text { h postinjury }\end{array}$ & [70] \\
\hline Readnower et al. (2010) & $\begin{array}{l}\text { Moderate blast-induced TBI, blast } \\
\text { exposure with peak pressure of } \\
120 \mathrm{kPa}\end{array}$ & $\begin{array}{l}44 \text { male Sprague-Dawley } \\
\text { rats, weighing } 250-300 \mathrm{~g} \text {, } \\
\text { ages not stated but } \\
\text { reports adult }\end{array}$ & Blast injury & $\begin{array}{l}\text { Single blast-induced injury exhibited BBB } \\
\text { breakdown in the cortex at three and } 24 \mathrm{~h} \\
\text { postinjury as measured by IgG antibody } \\
\text { staining compared with control rats }\end{array}$ & [72] \\
\hline Hicks et al. (1993) & $\begin{array}{l}\text { very mild TBI }(0.5 \mathrm{~atm}), \mathrm{mTBI}(1 \\
\text { atm) and moderate TBI }(2.2 \mathrm{~atm}) \\
\text { via fluid percussion injury device }\end{array}$ & $\begin{array}{l}11 \text { male Sprague-Dawley } \\
\text { rats, weighing } 330-400 \mathrm{~g} \text {, } \\
\text { ages not stated }\end{array}$ & Fluid-percussion injury & $\begin{array}{l}\mathrm{mTBI} \text { resulted in BBB disruption as shown by } \\
\text { presence of } \mathrm{IgG} \text { immunoreactivity }\end{array}$ & [73] \\
\hline Perez-Polo et al. (2013) & $\begin{array}{l}\text { mTBI, fluid percussion pulse } 1 \\
\text { atm }\end{array}$ & $\begin{array}{l}\text { male Sprague-Dawley } \\
\text { rats, weighing } 350-400 \mathrm{~g} \text {, } \\
\text { ages not stated }\end{array}$ & Fluid-percussion injury & $\begin{array}{l}\text { Single } \mathrm{mTBI} \text { resulted in a significant disruption } \\
\text { of BBB integrity, reflected by increased IgG } \\
\text { antibody and albumin in the brain } \\
\text { parenchyma, compared with the control group }\end{array}$ & [74] \\
\hline Marchi et al. (2013) & Subconcussive head hits & $\begin{array}{l}57 \text { human subjects } \\
\text { athletes, ages not stated } \\
\text { but reports college } \\
\text { atheletes }\end{array}$ & $\begin{array}{l}\text { Football-related } \\
\text { injuries, no players } \\
\text { experienced concussion }\end{array}$ & $\begin{array}{l}\text { Subconcussive injuries showed increased levels } \\
\text { of S100B, indicating BBB disruption; elevations } \\
\text { in S100B correlated with the number and } \\
\text { intensity of the injuries }\end{array}$ & [75] \\
\hline Deford et al. (2002) & $\begin{array}{l}\text { mTBI and rmTBI, drop-weight } 50 \text {, } \\
100 \text { or } 150 \mathrm{~g} \text { from } 40-\mathrm{cm} \text { height }\end{array}$ & $\begin{array}{l}117 \text { B6C3F1 male mice, } \\
\text { age } 9 \text { weeks }\end{array}$ & Drop-weight & $\begin{array}{l}\text { mTBI or rmTBI resulted in no evidence of BBB } \\
\text { breakdown; no detection of axonal injury as } \\
\text { measured by neurofilament } 68 \text { and APP } \\
\text { molecules }\end{array}$ & [76] \\
\hline
\end{tabular}

ACRM: American Congress of Rehabilitation Medicine; APP: Amyloid precursor protein; BBB: Blood-brain barrier; GCS: Glasgow Coma Scale; mTBI: Mild traumatic brain injury; NAA: N-acetyl aspartate; PTP: Permeability transition pore; rmTBI: Repetitive mTBI.

into a type of mTBI [19]. The 4th International Conference on Concussion acknowledged concussion as a subset of TBI but did not delineate the difference between concussion and mTBI [20]. In fact, the stated definition of concussion seems to greatly overlap with that of mTBI. Therefore, for the purpose of this review and given the controversy distinguishing the two terms, concussion and mTBI will be determined to be injuries of comparable severity.

\section{Mitochondria \& mitochondrial dysfunction following mTBI \& rmTBI}

Mitochondria are membrane-bound organelles responsible for energy production via cellular respiration, which is 15-times more efficient at generating the body's store of energy in the form of adenosine triphosphate (ATP) compared with nonmitochondrial dependent glycolysis alone [21]. The brain consumes $20 \%$ of total body oxygen for cellular respiration despite comprising only $2 \%$ of the body's weight; therefore, even slight deprivation of energy from dysfunctional mitochondria may impair neuronal function [22]. While its function of ATP production is important, mitochondria are also involved with other cellular processes. Mitochondrial dysfunction is associated with abnormalities in cellular function and reflects the complexity of this organelle's involvement in these processes.

Growing evidence points to mitochondrial dysfunction following rmTBI [12,23-25]. The mechanism of mitochondrial dysfunction in rmTBI may occur via opening of the mitochondrial permeability transition pore (PTP) and disruption of the mitochondrial membrane potential. Further, mitochondrial dysfunction has downstream 
effects leading to injury to the nervous system by activation of caspases, enzymes involved in programmed cell death and calpains, a particular group of calcium-activated proteases. Activation of these enzymes induces many downstream effects leading to negative neurological consequences including neuronal cell death, axonal injury and $\mathrm{BBB}$ compromise. We next review the evidence linking mitochondrial dysfunction to mTBI and rmTBI.

\section{Energetic markers \& evidence of mitochondrial impairment in mTBI \& rmTBI}

The functional state of the mitochondria following rmTBI has been indirectly assessed through the measurement of energetic biomarkers. Many of these studies used technologies such as magnetic resonance spectroscopy (MRS) that noninvasively quantify in vivo levels of biomarkers that reflect mitochondrial function. In particular, H-MRS and Phosphorus-MRS are widely employed to quantify levels of brain energetic biomarkers such as $N$-acetyl aspartate (NAA), ATP, lactate and nicotinamide adenine dinucleotide. The NAA molecule is synthesized from aspartate and acetyl CoA in the mitochondria [26], and represents the most visible peak in MRS scans of healthy human brains [27]. An increasing number of studies show that decreases in NAA levels may in fact be a better reflection of impaired mitochondrial function than neuronal death [26,28-30]. NAA is also suggested to be involved in neuronal mitochondrial energy production and helps the neurons to meet its high demand for ATP [31].

The disruption in NAA is seen in single mTBI. Govindaraju and colleagues observed decreases in NAA/Cr and NAA/Cho, markers of neuronal damage or disruption, in 14 human subjects with mTBI compared with 13 control subjects when measured within 1 month postinjury [32]. In addition, Son and colleagues reported a reduction in $\mathrm{NAA} / \mathrm{Cr}$ ratios in pericontusional regions in seven mTBI human subjects compared with 25 control subjects [33].

Disruption in energetic biomarkers is also evident in rmTBI. In a rodent study, decreased levels of ATP and other energetic markers was observed 2 days after rats were subjected to two mTBIs [23]. ATP, NAA and acetyl-CoA levels were maximally decreased when the interinjury interval was 3 days, even after a 7-day recovery period post second injury. By contrast, rats subjected to an interinjury interval of 5 days did not show differential levels compared with the control group. These results suggest a temporal window between the rmTBIs during which the brain is especially vulnerable and may lend itself to damage that is difficult to reverse.

In a follow-up proton MRS study conducted in human athletes, Vagnozzi and colleagues reported findings that support the presence of mitochondrial impairment following rmTBI [12]. Although this experiment was not originally designed to be an rmTBI study, 3 out of the 13 enrolled athletes endured a second concussion during the course of the study. The NAA/Cr ratio in singly concussed athletes was lower compared with control subjects at 3 days postinjury and recovered to control values at 30 days postinjury. Athletes who sustained a second concussive head injury had identical NAA/Cr ratio to that of athletes with a single concussion when measured at 3 days after the initial injury. However, the second injury (which occurred at 10, 12 and 13 days from the first one) was associated with a further decrease in NAA/Cr ratio post second injury with full restoration taking place at 45 days post initial injury. Thus, having two injuries within a certain window of time - which in this study was an interinjury period of at least 13 days - was associated with longer recovery of these energetic biomarkers. In addition, while singly concussed patients reported resolution of clinical symptoms (including physical, cognitive, emotional and sleep disturbances) within 3 days, all doubly concussed patients symptoms' persisted up to 30 days. Interestingly, the $\mathrm{NAA} / \mathrm{Cr}$ ratio did not recover at 30 days in the doubly concussed group despite resolution of clinical symptoms. Thus, patients with decreased NAA levels, signifying impaired brain metabolism, could have greater brain vulnerability to repeat concussion despite absence of clinical symptoms. These results suggest that brain vulnerability is still present in individuals with repetitive concussion despite the lack of detectable clinical symptoms, complicating the decision to 'clear' a patient to return to normal activities based on their report of recovery.

A later study from the same research group involving six doubly concussed nonprofessional male athletes with interinjury interval ranging between 9 and 21 days also demonstrated that the repeat concussion increased the time of recovery of NAA/Cr ratio to baseline as well as the persistence of clinical symptoms [34]. These results highlight the complexity of being able to appropriately and accurately determine full rmTBI recovery due to the discrepant clinical and biological data [12].

In addition to NAA, cerebral metabolic rate of glucose (CMRgluc), calculated through spectroscopy, can also provide evidence for brain vulnerability to repeat injury. Decreased CMRgluc levels suggest metabolic dysfunction, as glucose is a substrate used by the mitochondrial and nonmitochondrial methods of ATP production. Rats subjected to a single mTBI show decreased CMRgluc in the parietal cortex and the hippocampus [24]. CMRgluc levels decrease further when rats sustain a second injury within $24 \mathrm{~h}$ of the first injury, and remain decreased 3 days 
postinjury whereas rats subjected to a single mTBI returned to normal CMRgluc values. In contrast, rats that were subjected to 120-h interval rmTBI showed no significant changes compared with that in the group with single mTBI. The CMRgluc in this rmTBI group returned to the levels seen in the uninjured group 3 days after the second injury, suggesting no changes in the CMRgluc recovery time compared with the group with single mTBI. Overall, the lack of significant changes in CMRgluc drop and recovery time between single mTBI group and a longer interinjury interval $(120 \mathrm{~h}) \mathrm{rmTBI}$ group provide evidence that longer interinjury time interval results in less deleterious effects on the injured animal.

Decreased CMRgluc has also been observed in human rmTBI studies. Twelve war veterans with blast-induced rmTBI and persistent postconcussive symptoms exhibited decreased CMRgluc compared with control subjects with no history of brain injury [25]. The decrease in CMRgluc appears to be long lasting as the average time between the veterans' last blast exposure and the time at which CMRgluc was measured was 3.5 years.

As the evidence reviewed above suggests, there is growing evidence of mitochondrial dysfunction and brain vulnerability in rmTBI in animals and humans. Next, we review the mechanisms by which TBI may lead to mitochondrial dysfunction.

\section{Mechanism of mitochondrial impairment through the opening of mitochondrial PTP}

Mitochondrial dysfunction following TBI starts with an impact to the head. Acceleration-deceleration and rotational forces lead to deformation of neural tissue following TBI and trigger an outflow of potassium from the intracellular to extracellular space, with greater release following more severe injury [35] (Figure 1). Next, the elevation in extracellular potassium ions elicits a release of excitatory amino acids, notably glutamate, by the neurons at the site of the TBI; glutamate levels are also higher for more severe injury compared with mild TBI [36-39]. An in vitro study investigating the effect of $\mathrm{rmTBI}$ on cultured primary neurons found that glutamate release from neurons subjected to three injuries was significantly greater than those exposed to single or no injuries [40]. As a consequence of increased glutamate levels, NMDA receptors are overstimulated which, in turn, causes an increase in calcium levels [41]. TBI not only leads to increased mitochondrial $\mathrm{Ca}^{+}{ }^{+}$and glutamate levels, but also decreases the clearance of glutamate from the body by downregulating glial glutamate transporters GLT-1 and GLAST [42].

Overstimulation of NMDA receptors and disruption in $\mathrm{Ca} 2^{+}$levels contribute to mitochondrial membrane depolarization [43]. The resulting influx of excessive $\mathrm{Ca}^{+}$into the mitochondria instigates the opening of the mitochondrial PTP and disrupts the mitochondrial membrane potential via further $\mathrm{Ca}_{2}{ }^{+}$influx leading to further depolarization. This ultimately leads to mitochondrial impairment by disrupting the electrochemical gradient necessary for the production of ATP. In fact, postinjury administration of mitochondrial PTP inhibitor, cyclosporin $\mathrm{A}$, attenuates the disruption of the mitochondrial membrane potential and calcium homeostasis [44]. In sum, glutamate-induced NMDA overstimulation results in the disruption of $\mathrm{Ca}_{2}{ }^{+}$homeostasis in the mitochondria and the opening of the PTP, all of which contribute to mitochondrial impairment by disrupting the mitochondrial membrane potential (Figure 1).

Increased glutamate levels, the opening of PTP and the resulting disruption of $\mathrm{Ca} 2+$ homeostasis also affect the neuron's energy demand via depleting ATP stores. The ionic disruption activates ATP-dependent calcium pumps in an effort to restore homeostasis [43]. However, the impaired mitochondria are not able to produce the ATP needed to rectify the ionic disruption. Therefore, this process ultimately results in an increased demand of ATP within the context of lower supply.

Studies show that glutamate levels are indeed elevated in not only animals [36,45] but also humans with TBI. Ashwal and colleagues observed an increase in glutamate/glutamine levels in children and adolescents with TBI [46]. Further, increased glutamate/glutamine levels were observed in the white matter in mTBI human adults when measured at an average of 13 days postinjury [47].

\section{Mechanism of apoptosis \& axonal injury through activation of caspases in the mitochondria}

Apoptosis and axonal injury are established neurological consequences of TBI. In addition to reducing production of ATP needed for axonal functions, mitochondrial dysfunction activates caspases that trigger the death of neurons and cleaves structural proteins that maintain the axonal membrane [48]. Mitochondria play an integral role in apoptosis of neurons. The disruption of the mitochondrial transmembrane potential and the opening of PTP are important precipitating factors for apoptosis [49]. Cyclosporin A, a drug that blocks the mitochondrial PTP, was shown to help preserve the mitochondrial membrane potential and delay cell death [49,50]. The mitochondria also contain various proapoptotic proteins, such as cytochrome C. Cytochrome $\mathrm{C}$ is embedded in the inner 


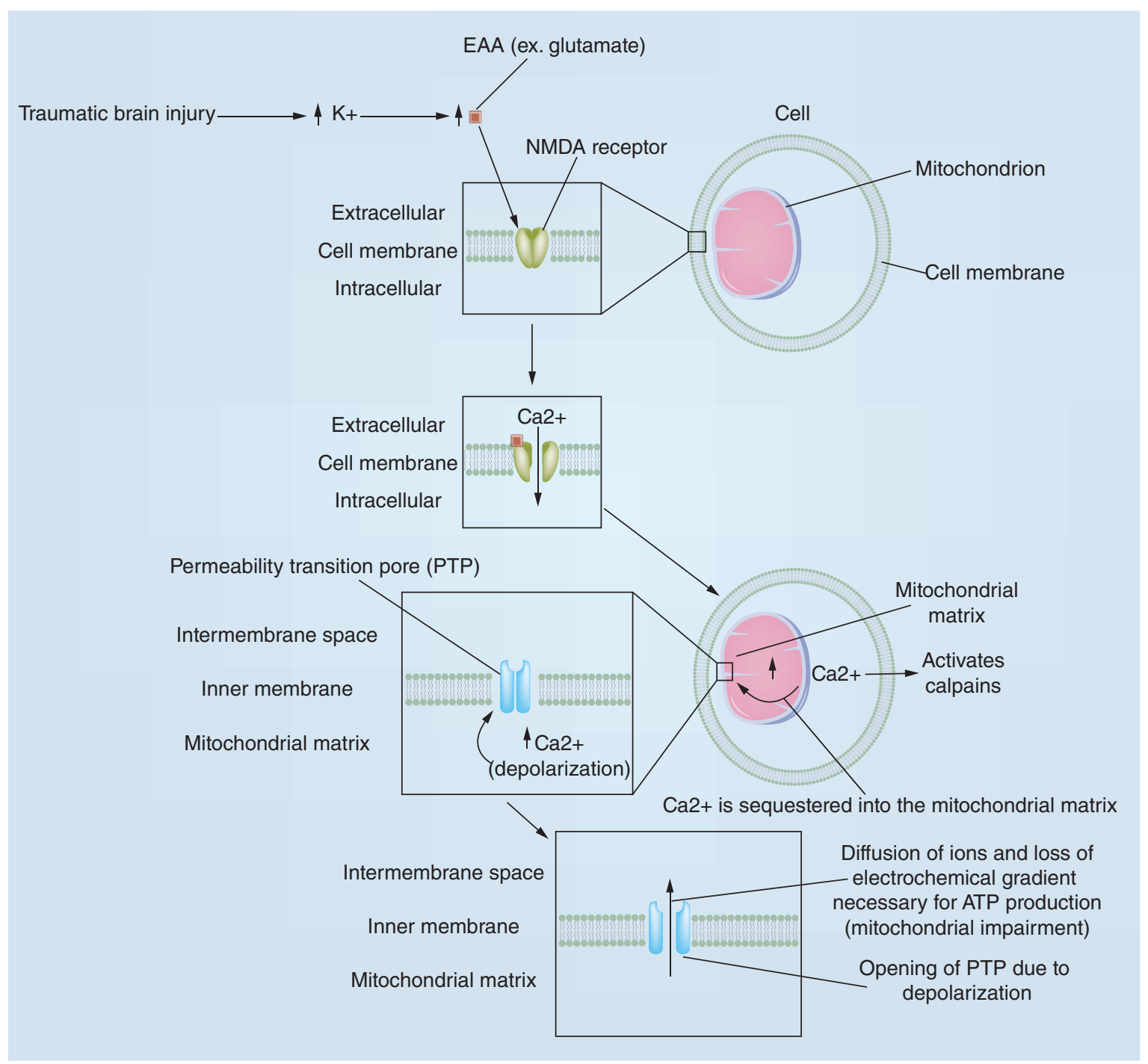

Figure 1. The process of mitochondrial impairment secondary to disruption of $\mathrm{Ca}_{2}{ }^{+}$homeostasis and opening of permeability transition pore.

PTP: Permeability transition pore.

mitochondrial membrane as part of the electron transport chain and mediates the release of itself and other proapoptotic factors during apoptosis [51]. TBI-associated mitochondrial impairment leads to the release of these proapoptotic proteins including cytochrome $\mathrm{C}$ (Figure 2). Proapoptotic proteins then trigger the activation of caspases, which are involved with apoptosis and axonal injury [52]. A study showed decreased levels of procaspase-3 and increased Bax, a proapoptotic protein, in mice subjected to mTBI. Procaspase- 3 is a proapoptotic protein and the precursor of caspase; thus a decrease in procaspase- 3 suggests increased conversion of the precursors to active caspases post mTBI [53]. In addition, an animal study by Abdul-Muneer and colleagues found that rats exposed to repeated mTBI showed increased activation of caspases compared with those subjected to single mTBI [54].

Caspase activation has detrimental consequences to axons. In a study by Buki and colleagues, a single traumatic head injury in rats resulted in the release of cytochrome $\mathrm{C}$ and activation of caspases within 15 min of the injury [52]. Axonal segments containing markers for cytochrome $\mathrm{C}$ and caspase activation revealed damages that are characteristic of a traumatic axonal injury such as focal cytoskeletal changes. 


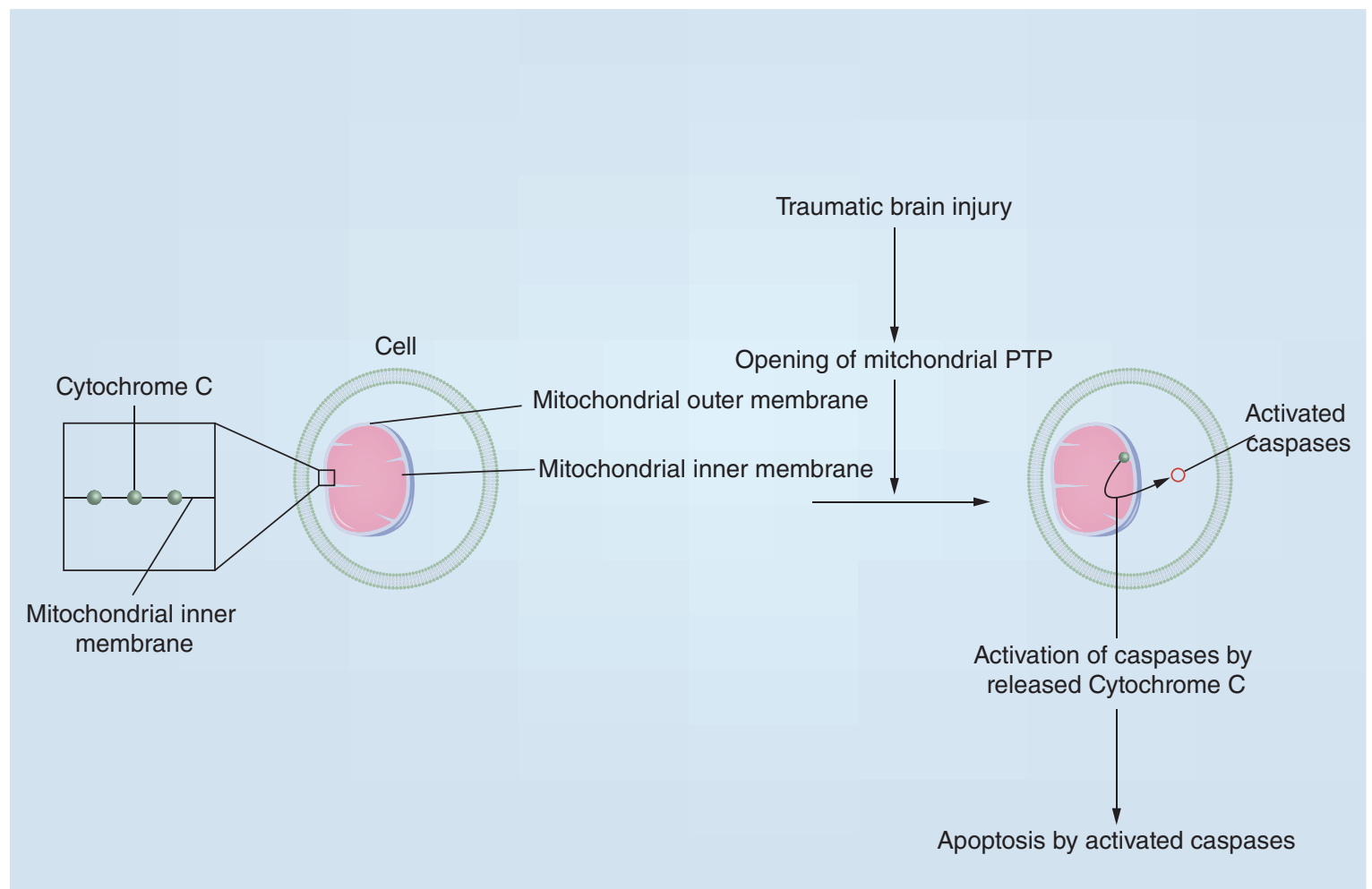

Figure 2. The mechanism of apoptosis secondary to release of cytochrome $\mathrm{C}$ from the mitochondria and the resulting activation of caspases.

\section{Mechanism of axonal injury through activation of calpains}

Calpains play an important role in the pathogenesis of traumatic axonal injury in animals and humans. Calpains are calcium-activated cysteine proteases that break down proteins in cells. Thus, these proteases will increase in activity with the increase in calcium concentration associated with rmTBI and loss of calcium homeostasis due to mitochondrial dysfunction [55,56] (Figure 1). In an rmTBI study by Huh and colleagues, calpain activation was seen in axons in subcortical white matter tracts of all injured rats (one, two or three successive injuries) at day 1 and increased with the number of injuries [57]. An animal study that investigated axonal injury in rats after TBI suggests that calpains are involved in axonal injury by damaging axonal cytoskeleton and activating downstream phosphatases [52]. Another study reports that administering calpain inhibitors to rats $10 \mathrm{~min}$ after a moderate TBI reduced the losses of cytoskeletal elements of neurons, neurofilament 200 and 68 [58]. Furthermore, an mTBI study showed that calpain-2 inhibitor prevented the degradation of MAP-2, a protein that plays a role in maintaining the cellular structure, in neurons [59].

Calpains are linked to mitochondrial dysfunction. In fact, certain calpains, such as Calpain 10, have been found in the mitochondria. In a study of rat mitochondria, Arrington and colleagues have found that an overexpression of this mitochondrial calpain resulted in morphological signs of mitochondrial dysfunction (i.e., fragmentation and swelling of the mitochondria) [60]. This study also found that Calpain 10 targeted parts of the electron transport chain in the mitochondria that are essential for aerobic cellular respiration. In addition, Calpain 10 may also be linked to mitochondrial permeability transition (PT) as cyclosporin A treatment in these rats preserved normal mitochondrial morphology. In addition, an in vitro study of neurons showed that inhibition of calpain by calpastatin protected mitochondria and neurons from the NMDA-mediated excitotoxicity [56]. Thus, calpains may also be involved in the mitochondrial dysfunction seen in patients with rmTBIs.

\section{Axonal injury in mTBI \& rmTBI}

Axonal injuries have been reported in rmTBI in animal studies [61] and these studies show a relationship between the mitochondria and such axonal injuries. As previously mentioned, mitochondrial dysfunction from mTBI results in axonal injury via the downstream effects of activating caspases and calpains; in fact, the activation of caspases 
and calpains is greater in rmTBI compared with single mTBI. As expected, axonal injury after rmTBI is worse compared with one after a single mTBI. For instance, more regions of axonal damage were present in pigs that sustained two mild rotational head injuries (10-15 min apart) compared with pigs with single injury [62]. Further, beta-amyloid precursor protein (APP) immunoreactivity (an indicator of traumatic axonal injury) in the brain of rmTBI mice was markedly elevated compared with single mTBI animals [63] with another study showing greater APP immunoreactivity in rats exposed to single and two mTBIs [64]. These results suggest that rmTBI results in worsened axonal damage compared with a single injury.

Evidence suggests that even a single mTBI leads to mitochondrial damage. For example, a single instance of mTBI has been shown to disrupt energetic biomarkers in both animal models [65] and humans [32,33]. Mitochondrial impairment after a single mTBI is also manifested through decreased expression of mitochondrial proteins. Brain tissues of rats subjected to single mTBI exhibited reduced expression of mitochondrial proteins involved in the electron transport chain and pyruvate dehydrogenase [66]. In an animal study, Amorini and colleagues found that rats exposed to single mTBI showed a transient decrease in ATP levels and three- to fivefold increase in the gene expression of enzymes involved in glycolysis, a significantly less efficient method of producing ATP that does not utilize the mitochondria [67]. These findings suggest that a single mTBI is sufficient to elicit mitochondrial impairment.

The detrimental effects seen in a single mTBI are heightened when the injury becomes repetitive. For example, rmTBI causes greater degree of neuronal damage compared with single mTBI [68,69]. An in vitro study by Slemmer and Weber found greater evidence of neuronal damage in hippocampal neurons after repeated mild stretch injuries than after a single mild stretch injury [70]. In fact, the study found that a single injury at subthreshold level of injury, which does not usually cause a noticeable cellular damage, resulted in cellular damage when it was repeated five- to six-times with a 2-min interinjury period. Thus, with evidence of greater neuronal and axonal damage associated with rmTBI and the link between mitochondrial impairment and these events, it would be reasonable to expect a greater severity of mitochondrial impairment in rmTBI. In fact, there is increasing evidence demonstrating that rmTBI has greater negative consequences for mitochondrial function than single mTBI.

Several studies have utilized cyclosporin A, a substance that inhibits the opening of mitochondrial PTP, in order to demonstrate the link between mitochondrial impairment and axonal damage. Rats given cyclosporin A 30 min before sustaining a single TBI exhibited reduced APP immunoreactivity, suggesting decreased axonal damage, when compared with the rats that were not pretreated with cyclosporin A [50]. Buki and colleagues also found reduced axonal damage in rats when they were administered cyclosporin A 30 min after a single TBI [52].

\section{rmTBI \& blood-brain barrier}

Thus far, our review discussed the mechanisms of mitochondrial impairment post-TBI, the downstream activation of caspases and calpains as well as their harmful effects on neurons and axons. While these mechanisms have been studied more extensively in moderate-to-severe head injuries, studies show that mitochondrial impairment and axonal injury are also indicated in mTBI. The mechanism involving increased glutamate levels, opening of mitochondrial PTP and the downstream disruption of the mitochondrial transmembrane potential are suggested in mTBI. Emerging evidence suggests altered biomarker levels and poorer clinical outcomes associated with rmTBI, especially with shorter interinjury interval, compared with single mTBI. In the next section, the review investigates the effects of mitochondrial dysfunction on the BBB, an important structure that protects the brain.

The mechanism of mitochondrial dysfunction may also be related to disruption of the BBB post mTBI. The $\mathrm{BBB}$ appropriately shields the brain from many substances in the blood; however, the integrity of the BBB may be compromised in pathological conditions, including Alzheimer's disease, brain tumors and multiple sclerosis [71]. BBB breakdown can lead to a number of negative outcomes, such as dysregulation of ions in brain interstitial fluid for optimal neuronal function and exposure of the brain to peripherally circulating agents [71]. One method of determining the integrity of BBB is by measuring Immunoglobulin $\mathrm{G}(\mathrm{IgG})$ antibody, which cannot cross an intact BBB. Thus, the presence of IgG antibody in the brain parenchyma would reflect BBB breakdown.

Several studies indicate the presence of BBB compromise after a TBI. Rats exposed to a single blast-induced injury exhibited BBB breakdown in the cortex at 3 and $24 \mathrm{~h}$ postinjury as measured by $\operatorname{IgG}$ antibody staining compared with control rats [72]. To note, BBB breakdown was also seen in other forms of TBI (in addition to blast-induced TBI injury). Hicks and colleagues also confirmed the presence of BBB breakdown in rats with mTBI as measured by IgG immunocytochemistry [73]. An animal study by Perez-Polo and colleagues found that rats subjected to single mTBI showed a significant disruption of BBB integrity, reflected by increased IgG antibody 
and albumin in the brain parenchyma, compared with the control group [74]. Evidence shows that BBB breakdown may be worse with rmTBI compared with mTBI. Three out of five rodents that sustained a single mTBI exhibited a small area of IgG staining at 24 and $48 \mathrm{~h}$ postinjury, suggesting some BBB breakdown [63]. Not surprisingly, four out of five rodents that sustained rmTBI exhibited a more noticeable and widespread area of IgG staining, suggesting a more significant compromise of the BBB with repeated injuries.

Although human subjects have been less studied, there is some evidence of BBB breakdown in humans after mTBI. Recent findings show evidence for BBB disruption in athletes with repeated subconcussive head injuries [75]. BBB disruption as measured by serum levels of $S 100 \beta$, a marker for BBB breakdown, was seen in football players who sustained subconcussive head injuries that were not severe enough to be qualified for a diagnosis of concussion. In support of the notion that repeated head injuries lead to a more negative prognosis compared with a single injury, changes in $S 100 \beta$ levels were positively correlated with the frequency and the severity of the head injuries.

Despite findings demonstrating the presence of BBB compromise in mTBI, other studies show that mTBI and even rmTBI do not provide a sufficient impact to cause the breakdown of the BBB. In a study by DeFord and colleagues, mice $(\mathrm{n}=117)$ that sustained head injuries using a weight-drop model (weights ranged from 50 to 150 grams dropped from $0.4-\mathrm{m}$ height) were measured for IgG detection [76]. Neither single mTBI nor rmTBI resulted in BBB breakdown. Additionally, there was no detection of axonal injury as measured by neurofilament 68 and APP molecules. On the other hand, the mice that sustained rmTBI using the 100 and 150 grams showed a significantly decreased cognitive function (measured via Morris water maze assessment) compared with noninjured and singly injured mice. Another study using a weight-drop model defined mild brain injury under the conditions of using heavier weights that were dropped at higher heights ( $450 \mathrm{~g}$ weights dropped from $1 \mathrm{~m}$ height) compared with DeFord's study [77]. This study reported diffuse axonal injury as well as posttraumatic brain edema, a sign of BBB dysfunction, in the rats exposed to mild brain injury. It is currently unclear whether the discrepant results are due to differences in drop weight, procedures, or other methodological differences. Additional research is necessary to refine animal models of TBI and the severity level necessary to initiate BBB compromise.

\section{Mitochondrial dysfunction, caspases, reactive oxygen species \& BBB}

As discussed previously, evidence suggests that head trauma leads to the activation of caspases via cytochrome $\mathrm{C}$, which can lead to apoptosis and axonal injury. The BBB is comprised of endothelial cells, basement membrane, tight junctions, astrocytic feet and pericytes, which are all involved with keeping the BBB intact [78] (Figure 3). Increased caspase activation (via increased cytokine concentration) is also associated with increased BBB breakdown and increased cell apoptosis [79]. This may suggest that increased caspase activation in mTBI may result in further apoptosis of the elements that are essential in maintaining the integrity of the BBB.

Further, it was described earlier that rmTBI may lead to mitochondrial PT via the disruption of the mitochondrial transmembrane potential and opening of the mitochondrial PTP; interestingly, this mechanism may also be involved with BBB breakdown through the production of reactive oxygen species (ROS), a group of free radicals. Opening of the mitochondrial PTP via calcium is suggested to be accompanied by increased mitochondrial production of ROS, suggesting that PT may augment mitochondrial oxidative stress [80]. Further, preventing opening of the mitochondrial PTP via the administration of cyclosporin A 15 min postinjury reduced the formation of reactive oxygen species [43].

An animal study by Abdul-Muneer and colleagues further investigated the role of ROS in increasing BBB permeability in mTBI and rmTBI [53] (Figure 4). Rats exposed to single mTBI (123-kPa shock-wave exposure) and repeated mTBI (with 24-h interinjury interval) showed increased levels of oxidative damage markers in the brain microvessels and increased ROS levels in the brain. Interestingly, rats exposed to repeated mTBI (with 24-h interinjury interval) showed an even greater increase in a marker of ROS generation compared with when they were exposed to single mTBI. These changes were temporally linked with a decreased expression of BBB tight-junction proteins compared with the control group. Further, rats exposed to single mTBI and rmTBI showed a similarly decreased expression of PDGFR- $\beta$, a marker of supporting pericytic cells of the BBB. There was also evidence for activation of metalloproteinases, which degrade basement membrane proteins and tight junctions, and the resulting increased expression of aquaporin channels (a water channel protein) around the perivascular region (specifically astrocyte end-feet) in the brain tissue of $\mathrm{mTBI}$ and rmTBI rats. The aquaporin channels are suggested to increase permeability of the BBB. In addition, an in vitro study of cultured neurons found that those subjected to three mTBIs showed greater release of ROS compared with those exposed to single or no mTBIs [39]. In another study, rats subjected to rmTBI (three injuries 5 days apart) exhibited increased markers of oxidative stress (lipid peroxidation) 


\section{Capillary in the brain: blood-brain barrier}

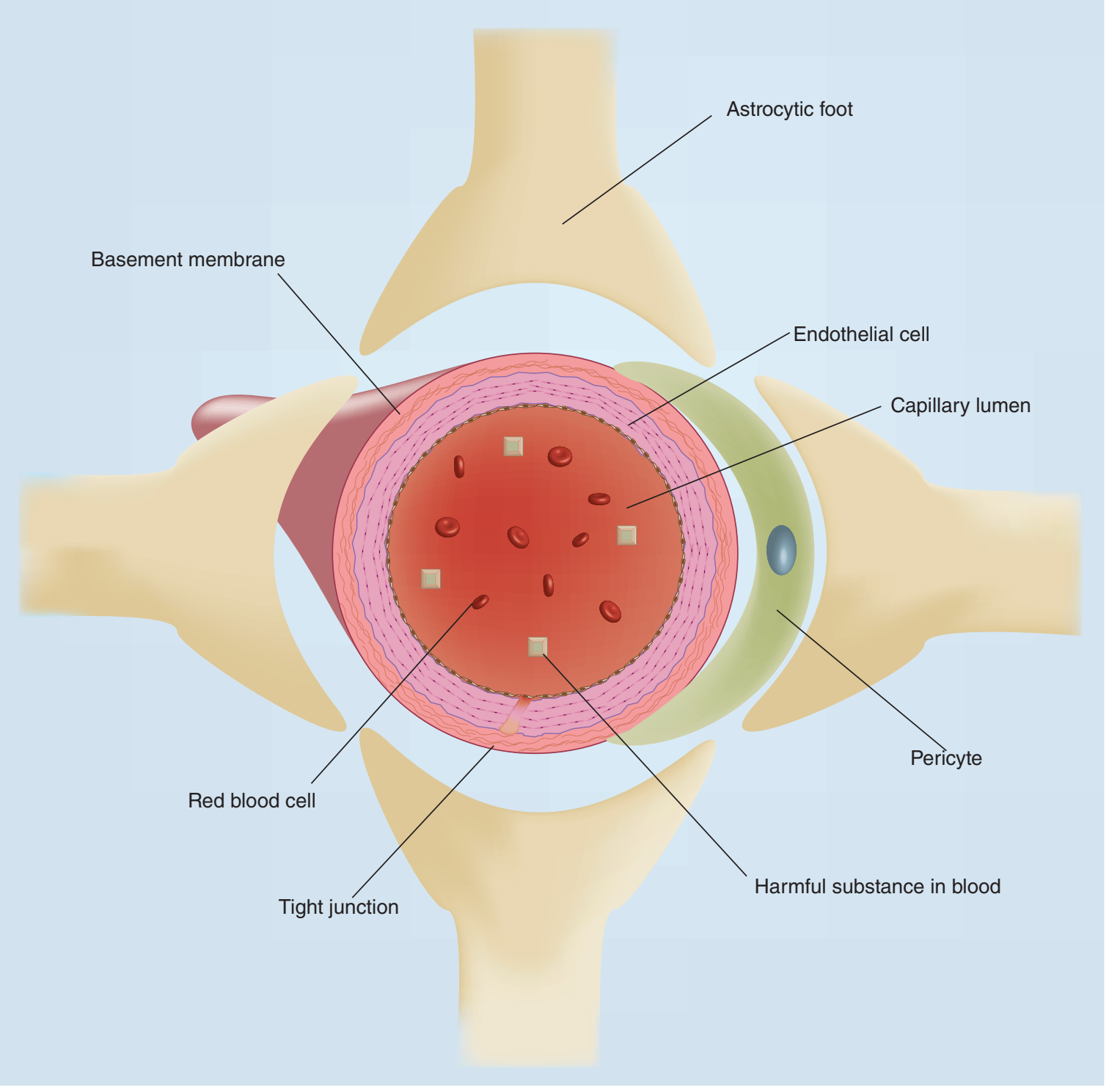

Figure 3. A schematic of blood-brain barrier and capillary in the brain. Structures boxed in blue are components of the BBB.

BBB: Blood-brain barrier.

in the brain tissue [81]. In fact, administration of progesterone, which has an antioxidative effect, resulted in less lipid peroxidation and better cognitive outcomes.

An experimental animal study using cell cultures from rat and human brains supports the role ROS has in disrupting the $\mathrm{BBB}$ [82]. This study found that ROS disrupted the integrity of the tight junctions comprising the BBB. Further, the transendothelial electrical resistance was decreased in ROS-injured rat and human brain endothelial cells, indicating a disruption in BBB integrity. ROS also initiated changes to the cytoskeleton and disappearance of proteins critical for maintaining tight junction integrity (occludin and claudin-5).

\section{Summary \& future perspective}

We reviewed the mechanism of mitochondrial impairment in TBI, including activation of caspases and calpains, and presented evidence of mitochondrial involvement in TBI through alterations in biomarkers. The neurological 


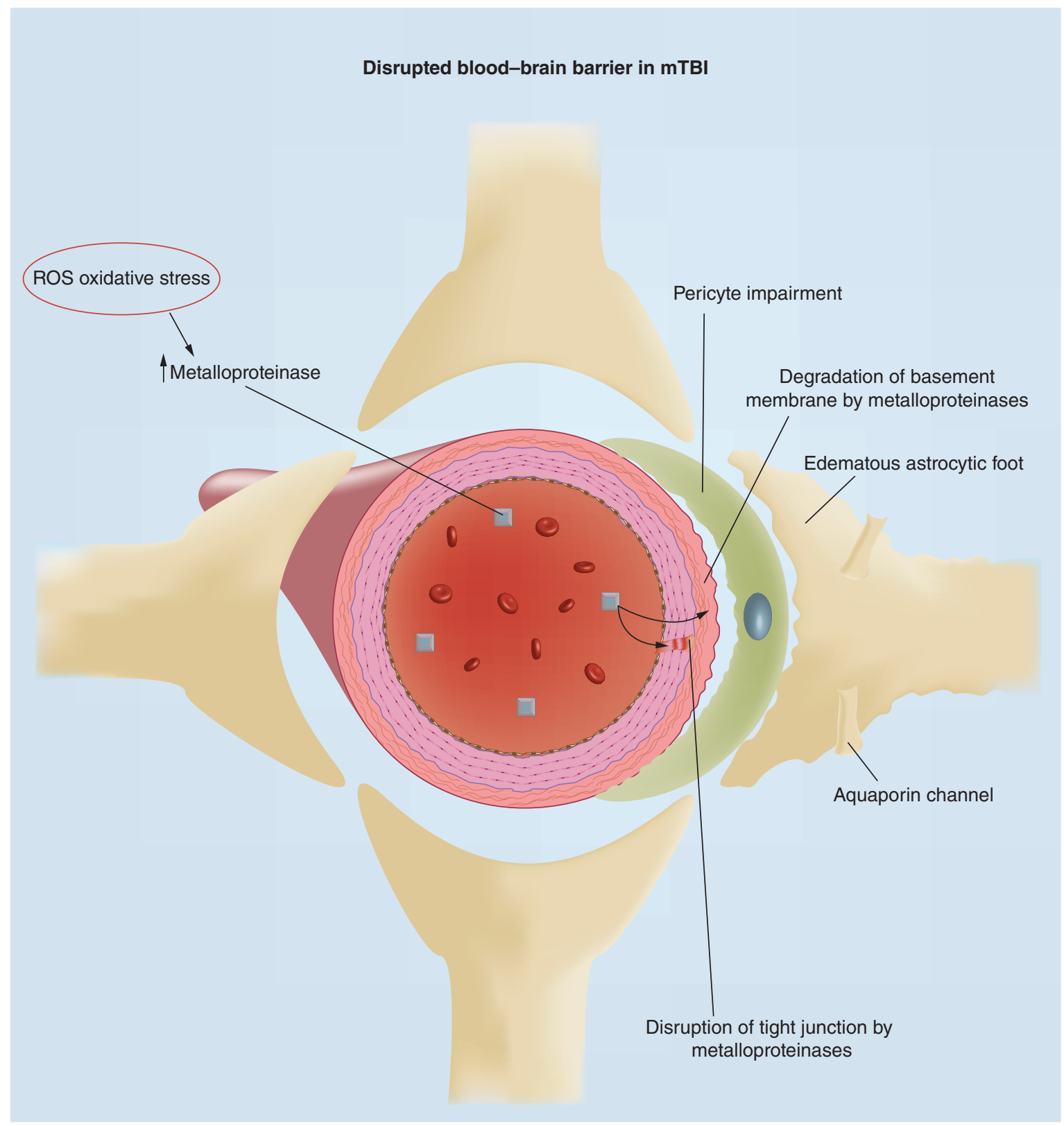

Figure 4. A schematic of a disrupted blood-brain barrier. The end results of the BBB impairment are: the disruption of tight junctions that hold together the endothelial cells of the blood vessels, the gradation of basement membrane and the impairment of pericytes and the edematous astrocytic feet that are parts of the perivascular component crucial for the integrity of BBB.

BBB: Blood-brain barrier.

consequences of mitochondrial impairment including neuronal apoptosis, axonal injury and BBB disruption were also highlighted. Further, we provided evidence for potentially worse mitochondrial dysfunction associated with rmTBI compared with single mTBI.

There remain several areas that would benefit from further research. First, there is a need to identify additional biomarkers of mitochondrial dysfunction. One promising marker that could be further explored is peripheral blood level of mitochondrial DNA post-TBI as a biomarker for cerebral mitochondrial energetics impairment [83]. Exploration of novel biomarkers is not only important in determining the level of mitochondrial dysfunction but also understanding its pathophysiology. For example, patients with certain genomic variant of mitochondrial DNA, haplogroup K, were reported to have a more favorable outcome in Glasglow Outcome Score post-TBI [84]. 
Increasing age is a known strong determinant of worse outcomes of TBI. Patients with haplogroup K showed a slower decline in Glasglow Outcome Score with increasing age compared other haplogroups. This suggests that there may be an inherent link between mitochondrial genome and outcome of TBI. It would be meaningful to explore this further in order to determine the role that this particular mitochondrial genomic variant has in the pathophysiology of mitochondrial dysfunction.

Another area of future research is validating animal models of mTBI. There are several different methods of inducing injury in animal studies including blast and drop-weight models. While these models are valuable because they mimic different situations of TBI in the real world, it would be interesting to consider if the methods of injury have an impact on the severity of TBI. In fact, an animal study comparing lateral fluid percussion model and weight-drop with hypoxia model of comparable injury severity found discrepancies in motor recovery periods (the rats under the weight-drop model recovered by 14 days vs 6 weeks for the lateral fluid percussion model), learning and memory deficits (present for lateral fluid percussion model vs absent in weight-drop model) as well as severity of neuronal degeneration (greater degree of neuronal degeneration for lateral fluid percussion model) [85]. Thus, even with similar injury severity, a certain mode of injury may result in a more detrimental effect compared with another mode of injury. Studying these injury models more thoroughly will allow future investigations to help design experiments with more accurate level of injury severity and allow comparisons between studies with different injury methods.

Many rmTBI animal studies discussed in this review subjected the animals to two injuries. As these injuries tend to occur more frequently in certain professions, it would be important to study models that subject the animals to more than two injuries to further investigate the degree of cumulative effects of these repeated injuries. With regard to the critical interinjury interval period, it would be helpful to identify a temporal window during which subsequent injury causes a cumulative harm. Understandably, it is difficult to determine this window using animal models because the temporal window in the animal model may not translate to humans. Careful investigations with recruitment of real-life TBI patients and monitoring need to be done in order to determine this critical temporal window. By determining the critical window, one can better estimate the prognosis of negative consequences associated with repetitive TBIs with a certain interinjury interval.

Evidence also suggests an association between neurodegenerative and psychiatric disorders and TBI [86-88]. For example, increased risks of neurodegenerative disorders such as Alzheimer's disease and amyotrophic lateral sclerosis are suggested for patients post TBI [86]. Similarly, patients with TBI have increased risks of psychiatric disorders such as depression, bipolar disorders and post-traumatic stress disorder (PTSD) [88,89]. Considering the link between mitochondria and TBI, it would be interesting to investigate whether or not there is an overlap of mechanism between these psychiatric disease processes and TBI.

There has also been emerging research on the different types of therapy for patients post TBI. Examples include hyperbaric oxygen therapy, hypothermia therapy and transcranial light therapy [90-94]. Specifically for rmTBI, Huang and colleagues found that rats subjected to rmTBI (two injuries with a 3-day interinjury interval) treated with daily hyperbaric oxygen therapy during the interinjury period had reduced histopathological gliosis and pathological MRI finding associated with the second injury [90]. Further, rats exposed to rmTBI (two injuries) that were treated with 1-h of hypothermia an hour after the second injury had axons with decreased APP density compared with the untreated group [93]. This study highlights that even a delayed treatment of hypothermia may still have therapeutic effects in rmTBI. Further research in the field of treatment is necessary as there is still debate among the efficacies of different therapies.

\section{Acknowledgements}

The authors thank A Reagan at the National Center for PTSD, VA Boston Healthcare System for assistance with preliminary research and references that helped complete the manuscript.

Financial \& competing interests disclosure

Support for this research was provided by VA SPiRe award I21RX001594 (J Hayes). The authors have no other relevant affiliations for financial involvement with any organization or entity with a financial interest in or financial conflict with the subject matter or materials discussed in the manuscript apart from those disclosed.

No writing assistance was utilized in the production of this manuscript 
Open access

This work is licensed under the Creative Commons Attribution 4.0 License. To view a copy of this license, visit http:// creativecommons.org/licenses/by/4.0/

\section{Executive summary}

\section{Background}

- Mild traumatic brain injury (mTBI) is a significant national health concern and there is growing evidence that repetitive $\mathrm{mTBI}$ ( $\mathrm{rmTBI}$ ) can cause long-term change in brain structure and function. The purpose of this review is to synthesize the mechanism of mitochondrial dysfunction in rmTBI and its downstream effects on neuronal cell death, axonal injury and blood-brain barrier (BBB) compromise.

Findings

- Evidence suggests that $\mathrm{mTBI}$ is severe enough to induce mitochondrial dysfunction. The resulting mitochondrial dysfunction has been shown to trigger a cascade of events including ionic changes and glutamate excitoxicity that lead to activation of enzymes known as caspases and calpains. Activation of these enzymes induces many downstream effects leading to negative neurological consequences including neuronal cell death, axonal injury and BBB compromise. In addition, compared with an isolated mTBI, research suggests that repeated mTBI (rmTBI) may lead to more severe neurological consequences.

Conclusion \& future perspective

- The findings as a whole demonstrate that the mechanisms of mitochondrial impairment, axonal injury and BBB disruption are interconnected and very complex. In the realm of rmTBI, there may be a critical temporal window of vulnerability between injuries during which damage caused by the subsequent injury is more harmful. Further areas of research include biomarkers, different injury models, long-term effects, association with other diseases and therapy. With practical relevance of rmTBI to the general population and certain professions, this topic remains an important field of further research.

\section{References}

1. Langlois JA, Rutland-Brown W, Thomas KE. Traumatic brain injury in the United States: emergency department visits, hospitalizations, and deaths. Department of Health and Human Services, Centers for Disease Control and Prevention, Division of Acute Care, Rehabilitation Research and Disability Prevention, National Center for Injury Prevention and Control (2004). https://www.cdc.gov/traumaticbraininjury/pdf/tbi_in_the_us.pdf

2. Mccrory P, Meeuwisse W, Johnston K et al. Consensus statement on concussion in sport: the 3rd International Conference on Concussion in Sport held in Zurich, November 2008. J. Athl. Train. 44(4), 434-448 (2009).

3. Benzinger TL, Brody D, Cardin S et al. Blast-related brain injury: imaging for clinical and research applications: report of the 2008 St. Louis workshop. J. Neurotrauma 26(12), 2127-2144 (2009).

4. Faul M, Xu L, Wald MM, Coronado V. Traumatic brain injury in the United States. Emergency Department Visits, Hospitalizations and Deaths 2006-2010 (2010). https://www.cdc.gov/traumaticbraininjury/pdf/blue_book.pdf

5. Mccrea M, Iverson GL, Mcallister TW et al. An integrated review of recovery after mild traumatic brain injury (MTBI): implications for clinical management. Clin. Neuropsychol. 23(8), 1368-1390 (2009).

6. Talavage TM, Nauman EA, Breedlove EL et al. Functionally-detected cognitive impairment in high school football players without clinically-diagnosed concussion. J. Neurotrauma 31(4), 327-338 (2014).

7. Guskiewicz KM, Mccrea M, Marshall SW et al. Cumulative effects associated with recurrent concussion in collegiate football players: the NCAA Concussion Study. JAMA 290(19), 2549-2555 (2003).

8. Gaetz M, Goodman D, Weinberg H. Electrophysiological evidence for the cumulative effects of concussion. Brain Inj. 14(12), 1077-1088 (2000).

9. Iverson GL, Gaetz M, Lovell MR, Collins MW. Cumulative effects of concussion in amateur athletes. Brain Inj. 18(5), 433-443 (2004).

10. Collins MW, Lovell MR, Iverson GL, Cantu RC, Maroon JC, Field M. Cumulative effects of concussion in high school athletes. Neurosurgery 51(5), 1175-1181 (2002).

11. Moser RS, Schatz P. Enduring effects of concussion in youth athletes. Arch. Clin. Neuropsychol. 17(1), 91-100 (2002).

12. Vagnozzi R, Signoretti S, Tavazzi B et al. Temporal window of metabolic brain vulnerability to concussion: a pilot $1 \mathrm{H}$-magnetic resonance spectroscopic study in concussed athletes - Part III. Neurosurgery 62(6), 1286-1296 (2008).

13. Iverson G, Brooks B, Lovell M, Collins M. No cumulative effects for one or two previous concussions. Br. J. Sports Med. 40(1), 72-75 (2006).

14. Cernak I, Noble-Haeusslein LJ. Traumatic brain injury: an overview of pathobiology with emphasis on military populations. J. Cereb. Blood Flow Metab. 30(2), 255-266 (2010). 
15. Hayes JP, Morey RA, Tupler LA. A case of frontal neuropsychological and neuroimaging signs following multiple primary-blast exposure. Neurocase 18(3), 258-269 (2012).

16. Mckee AC, Cantu RC, Nowinski CJ et al. Chronic traumatic encephalopathy in athletes: progressive tauopathy after repetitive head injury. J. Neuropathol Exp. Neurol. 68(7), 709-735 (2009).

17. Goldstein LE, Mckee AC, Stanton PK. Considerations for animal models of blast-related traumatic brain injury and chronic traumatic encephalopathy. Alzheimers Res. Ther. 6(5), 64 (2014).

18. Goldstein LE, Fisher AM, Tagge CA et al. Chronic traumatic encephalopathy in blast-exposed military veterans and a blast neurotrauma mouse model. Sci. Transl. Med. 4(134), 134ra60-134ra60 (2012).

19. Sharp DJ, Jenkins PO. Concussion is confusing us all. Pract. Neurol. 15(3), 172-186 (2015).

20. McCrory P, Meeuwisse W, Aubry M et al. Consensus statement on concussion in sport - the 4th International Conference on Concussion in Sport held in Zurich, November 2012. Br. J. Sports Med. 47(5), 250-258 (2013).

21. Alberts B, Johnson A, Lewis J, Raff M, Roberts K, Walter P. The mitochondrion. Molecular Biology of the Cell (4th Edition). Garland Science, NY, USA, 767-768 (2002).

22. Singh M, Dykens JA, Simpkins JW. Novel mechanisms for estrogen-induced neuroprotection. Exp. Biol. Med. 231(5), 514-521 (2006).

23. Vagnozzi R, Tavazzi B, Signoretti $S$ et al. Temporal window of metabolic brain vulnerability to concussions: mitochondrial-related impairment - Part I. Neurosurgery 61(2), 379-389 (2007).

24. Prins ML, Alexander D, Giza CC, Hovda DA. Repeated mild traumatic brain injury: mechanisms of cerebral vulnerability. $J$. Neurotrauma 30(1), 30-38 (2013).

25. Peskind ER, Petrie EC, Cross DJ et al. Cerebrocerebellar hypometabolism associated with repetitive blast exposure mild traumatic brain injury in 12 Iraq war Veterans with persistent post-concussive symptoms. Neuroimage 54 S76-S82 (2011).

26. Clark J. N-acetyl aspartate: a marker for neuronal loss or mitochondrial dysfunction. Dev. Neurosci. 20(4-5), 271-276 (1998).

27. Moffett JR, Arun P, Ariyannur PS, Namboodiri AM. N-Acetylaspartate reductions in brain injury: impact on post-injury neuroenergetics, lipid synthesis, and protein acetylation. Front. Neuroenergetics 511 (2013).

28. De Stefano N, Matthews P, Ford B, Genge A, Karpati G, Arnold D. Short-term dichloroacetate treatment improves indices of cerebral metabolism in patients with mitochondrial disorders. Neurology 45(6), 1193-1198 (1995).

29. Stork C, Renshaw PF. Mitochondrial dysfunction in bipolar disorder: evidence from magnetic resonance spectroscopy research. Mol. Psychiatry 10(10), 90-19 (2005).

30. Di Pietro V, Amorini AM, Tavazzi B et al. The molecular mechanisms affecting $N$-acetylaspartate homeostasis following experimental graded traumatic brain injury. Mol. Med., 20(1), 147 (2014).

31. Madhavarao C, Chinopoulos C, Chandrasekaran K, Namboodiri M. Characterization of the $N$-acetylaspartate biosynthetic enzyme from rat brain. J. Neurochem. 86(4), 824-835 (2003).

32. Govindaraju V, Gauger GE, Manley GT, Ebel A, Meeker M, Maudsley AA. Volumetric proton spectroscopic imaging of mild traumatic brain injury. AJNR Am. J. Neuroradiol. 25(5), 730-737 (2004).

33. Son B, Park CK, Choi BG et al. Metabolic changes in pericontusional oedematous areas in mild head injury evaluated by $1 \mathrm{H}$ MRS. Acta. Neurochir. Suppl. 76, 13-16 (2000).

34. Lazzarino G, Vagnozzi R, Signoretti $S$ et al. The importance of restriction from physical activity in the metabolic recovery of concussed brain. Brain Injury-Pathogenesis, Monitoring, Recovery and Management. InTech, Rijeka, Croatia (2012).

35. Katayama Y, Becker DP, Tamura T, Hovda DA. Massive increases in extracellular potassium and the indiscriminate release of glutamate following concussive brain injury. J. Neurosurg. 73(6), 889-900 (1990).

36. Hinzman JM, Thomas TC, Burmeister JJ et al. Diffuse brain injury elevates tonic glutamate levels and potassium-evoked glutamate release in discrete brain regions at two days post-injury: an enzyme-based microelectrode array study. J. Neurotrauma 27(5), 889-899 (2010).

37. Faden AL, Demediuk P, Panter SS, Vink R. The role of excitatory amino acids and NMDA receptors in traumatic brain injury. Science 244(4906), 798 (1989).

38. Globus MYT, Alonso O, Dietrich WD, Busto R, Ginsberg MD. Glutamate release and free radical production following brain injury: effects of posttraumatic hypothermia. J. Neurochem. 65(4), 1704-1711 (1995).

39. Amorini AM, Lazzarino G, Di Pietro V et al. Severity of experimental traumatic brain injury modulates changes in concentrations of cerebral free amino acids. J. Cell. Mol. Med. 21(3), 530-542 (2017).

40. Zander NE, Piehler T, Banton R, Benjamin R. Effects of repetitive low-pressure explosive blast on primary neurons and mixed cultures. J. Neurosci. Res. 94(9), 827-836 (2016).

41. Fineman I, Hovda DA, Smith M, Yoshino A, Becker DP. Concussive brain injury is associated with a prolonged accumulation of calcium: a 45 Ca autoradiographic study. Brain Res. 624(1), 94-102 (1993). 
42. Raghavendra Rao VL, Başkaya MK, Doğan A, Rothstein JD, Dempsey RJ. Traumatic brain injury down-regulates glial glutamate transporter (GLT-1 and GLAST) proteins in rat brain. J. Neurochem. 70(5), 2020-2027 (1998).

43. Schinder AF, Olson EC, Spitzer NC, Montal M. Mitochondrial dysfunction is a primary event in glutamate neurotoxicity. $J$. Neurosci. 16(19), 6125-6133 (1996).

44. Sullivan PG, Thompson MB, Scheff SW. Cyclosporin A attenuates acute mitochondrial dysfunction following traumatic brain injury. Exp. Neurol. 160(1), 226-234 (1999).

45. Nilsson P, Hillered L, Ponten U, Ungerstedt U. Changes in cortical extracellular levels of energy-related metabolites and amino acids following concussive brain injury in rats. J. Cereb. Blood Flow Metab. 10(5), 631-637 (1990).

46. Ashwal S, Holshouser B, Tong K et al. Proton spectroscopy detected myoinositol in children with traumatic brain injury. Pediatr. Res. 56(4), 630-638 (2004).

47. Yeo RA, Gasparovic C, Merideth F, Ruhl D, Doezema D, Mayer AR. A longitudinal proton magnetic resonance spectroscopy study of mild traumatic brain injury. J. Neurotrauma 28(1), 1-11 (2011).

48. Hill CS, Coleman MP, Menon DK. Traumatic axonal injury: mechanisms and translational opportunities. Trends Neurosci. 9(5), 311-324 (2016).

49. Hirsch T, Susin S, Marzo I, Marchetti P, Zamzami N, Kroemer G. Mitochondrial permeability transition in apoptosis and necrosis. Cell Biol. Toxicol. 14(2), 141-145 (1998).

50. Okonkwo DO, Povlishock JT. An intrathecal bolus of cyclosporin A before injury preserves mitochondrial integrity and attenuates axonal disruption in traumatic brain injury. J. Cereb. Blood Flow Metab. 19(4), 443-451 (1999).

51. Kroemer G, Galluzzi L, Brenner C. Mitochondrial membrane permeabilization in cell death. Physiol. Rev. 87(1), 99-163 (2007).

52. Büki A, Okonkwo DO, Wang KK, Povlishock JT. Cytochrome C release and caspase activation in traumatic axonal injury. J. Neurosci. 20(8), 2825-2834 (2000).

53. Tweedie D, Milman A, Holloway HW et al. Apoptotic and behavioral sequelae of mild brain trauma in mice. J. Neurosci. Res. 85(4), 805-815 (2007).

54. Abdul-Muneer P, Schuetz H, Wang F et al. Induction of oxidative and nitrosative damage leads to cerebrovascular inflammation in an animal model of mild traumatic brain injury induced by primary blast. Free Radical Bio. Med. 60, 282-291 (2013).

55. Cheng JP, Shaw KE, Monaco CM et al. A relatively brief exposure to environmental enrichment after experimental traumatic brain injury confers long-term cognitive benefits. J. Neurotrauma 29(17), 2684-2688 (2012).

56. Jahani-Asl A, Germain M, Slack RS. Mitochondria: joining forces to thwart cell death. Biochim. Biophys. Acta 1802(1), 162-166 (2010).

57. Huh JW, Widing AG, Raghupathi R. Repetitive mild non-contusive brain trauma in immature rats exacerbates traumatic axonal injury and axonal calpain activation: a preliminary report. J. Neurotrauma 24(1), 15-27 (2007).

58. Posmantur R, Kampfl A, Siman R et al. A calpain inhibitor attenuates cortical cytoskeletal protein loss after experimental traumatic brain injury in the rat. Neuroscience 77(3), 875-888 (1997).

59. Atalay B, Caner H, Can A, Cekinmez M. Attenuation of microtubule associated protein-2 degradation after mild head injury by mexiletine and calpain-2 inhibitor. Br. J. Neurosurg. 21(3), 281-287 (2007).

60. Arrington DD, Van Vleet TR, Schnellmann RG. Calpain 10: a mitochondrial calpain and its role in calcium-induced mitochondrial dysfunction. Am. J. Physiol. Cell Physiol. 291(6), C1159-C1171 (2006).

61. Miyauchi T, Wei EP, Povlishock JT. Therapeutic targeting of the axonal and microvascular change associated with repetitive mild traumatic brain injury. J. Neurotrauma 30(19), 1664-1671 (2013).

62. Raghupathi R, Mehr MF, Helfaer MA, Margulies SS. Traumatic axonal injury is exacerbated following repetitive closed head injury in the neonatal pig. J. Neurotrauma 21(3), 307-316 (2004).

63. Laurer HL, Bareyre FM, Lee VM et al. Mild head injury increasing the brain's vulnerability to a second concussive impact. J. Neurosurg. 95(5), 859-870 (2001).

64. Shitaka Y, Tran HT, Bennett RE et al. Repetitive closed-skull traumatic brain injury in mice causes persistent multifocal axonal injury and microglial reactivity. J. Neuropathol. Exp. Neurol. 70(7), 551-567 (2011).

65. Yang MS, Dewitt DS, Becker DP, Hayes RL. Regional brain metabolite levels following mild experimental head injury in the cat. J. Neurosurg. 63(4), 617-621 (1985).

66. Xing G, Barry ES, Benford B et al. Impact of repeated stress on traumatic brain injury-induced mitochondrial electron transport chain expression and behavioral responses in rats. Front. Neurol. 4(196), 1-13 (2013).

67. Amorini AM, Lazzarino G, Di Pietro V et al. Metabolic, enzymatic and gene involvement in cerebral glucose dysmetabolism after traumatic brain injury. BBA-Mol. Basis Dis. 1862(4), 679-687 (2016).

68. Uryu $\mathrm{K}$, Laurer $\mathrm{H}$, Mcintosh $\mathrm{T}$ et al. Repetitive mild brain trauma accelerates $\mathrm{A} \beta$ deposition, lipid peroxidation, and cognitive impairment in a transgenic mouse model of Alzheimer amyloidosis. J. Neurosci. 22(2), 446-454 (2002). 
69. Slemmer JE, Matser EJ, De Zeeuw CI, Weber JT. Repeated mild injury causes cumulative damage to hippocampal cells. Brain 125(12), 2699-2709 (2002).

70. Slemmer JE, Weber JT, De Zeeuw CI. Cell death, glial protein alterations and elevated S-100 $\beta$ release in cerebellar cell cultures following mechanically induced trauma. Neurobiol. Dis. 15(3), 563-572 (2004).

71. Abbott NJ, Rönnbäck L, Hansson E. Astrocyte-endothelial interactions at the blood-brain barrier. Nat. Rev. Neurosci. 7(1), 41-53 (2006).

72. Readnower RD, Chavko M, Adeeb $S$ et al. Increase in blood-brain barrier permeability, oxidative stress, and activated microglia in a rat model of blast-induced traumatic brain injury. J. Neurosci. Res. 88(16), 3530-3539 (2010).

73. Hicks R, Smith D, Lowenstein D, Marie RS, Mcintosh T. Mild experimental brain injury in the rat induces cognitive deficits associated with regional neuronal loss in the hippocampus. J. Neurotrauma 10(4), 405-414 (1993).

74. Perez-Polo JR, Rea HC, Johnson KM et al. Inflammatory consequences in a rodent model of mild traumatic brain injury. J. Neurotrauma 30(9), 727-740 (2013).

75. Marchi N, Bazarian JJ, Puvenna V et al. Consequences of repeated blood-brain barrier disruption in football players. PLoS ONE 8(3), e56805 (2013).

76. Deford SM, Wilson MS, Rice AC et al. Repeated mild brain injuries result in cognitive impairment in B6C3F1 mice. J. Neurotrauma 19(4), 427-438 (2002).

77. Abd-Elfattah Foda MA, Marmarou A. A new model of diffuse brain injury in rats: Part II: morphological characterization. J. Neurosurg. 80(2), 301-313 (1994).

78. Ballabh P, Braun A, Nedergaard M. The blood-brain barrier: an overview: structure, regulation, and clinical implications. Neurobiol. Diss. 16(1), 1-13 (2004).

79. Lopez-Ramirez MA, Fischer R, Torres-Badillo CC et al. Role of caspases in cytokine-induced barrier breakdown in human brain endothelial cells. J. Immunol. 189(6), 3130-3139 (2012).

80. Maciel EN, Vercesi AE, Castilho RF. Oxidative stress in $\mathrm{Ca}_{2}{ }^{+}$-induced membrane permeability transition in brain mitochondria. J. Neurochem. 79(6), 1237-1245 (2001).

81. Webster KM, Wright DK, Sun M et al. Progesterone treatment reduces neuroinflammation, oxidative stress and brain damage and improves long-term outcomes in a rat model of repeated mild traumatic brain injury. J. Neuroinflammation 12(1), 238 (2015).

82. Schreibelt G, Kooij G, Reijerkerk A et al. Reactive oxygen species alter brain endothelial tight junction dynamics via RhoA, PI3 kinase, and PKB signaling. FASEB J. 21(13), 3666-3676 (2007).

83. Kilbaugh TJ, Lvova M, Karlsson M et al. Peripheral blood mitochondrial DNA as a biomarker of cerebral mitochondrial dysfunction following traumatic brain Injury in a porcine model. PLoS ONE 10(6), e0130927 (2015).

84. Bulstrode H, Nicoll JA, Hudson G, Chinnery PF, Di Pietro V, Belli A. Mitochondrial DNA and traumatic brain injury. Ann Neurol. 75(2), 186-195 (2014).

85. Hallam TM, Candace FL, Folkerts MM et al. Comparison of behavioral deficits and acute neuronal degeneration in rat lateral fluid percussion and weight-drop brain injury models. J. Neurotrauma 21(5), 521-539 (2004).

86. Gupta RK, Prasad S. Age-dependent alterations in the interactions of NF-kB and N-myc with GLT-1/EAAT2 promoter in the pericontusional cortex of mice subjected to traumatic brain injury. Mol. Neurobiol. 53(5), 3377-3388 (2016).

87. Perry DC, Sturm VE, Peterson MJ et al. Association of traumatic brain injury with subsequent neurological and psychiatric disease: a meta-analysis. J. Neurosurg. 124(2), 511-526 (2016).

88. Hoge CW, Mcgurk D, Thomas JL, Cox AL, Engel CC, Castro CA. Mild traumatic brain injury in US soldiers returning from Iraq. $N$. Eng. J. Med. 358(5), 453-463 (2008).

89. Yoshimi N, Futamura T, Bergen S et al. Cerebrospinal fluid metabolomics identifies a key role of isocitrate dehydrogenase in bipolar disorder: evidence in support of mitochondrial dysfunction hypothesis. Mol. Psychiatry 21(11), 1504-1510 (2016).

90. Huang L, Obernaus A, Hamer M, Zhang JH. Neuroprotective effect of hyperbaric oxygen therapy in a juvenile rat model of repetitive mild traumatic brain injury. Med. Gas Res. 6(4), 187-193 (2016).

91. Polderman KH. Mechanisms of action, physiological effects, and complications of hypothermia. Crit. Care Med. 37(7), S186-S202 (2009).

92. Miyauchi T, Wei EP, Povlishock JT. Therapeutic targeting of the axonal and microvascular change associated with repetitive mild traumatic brain injury. J. Neurotrauma 30(19), 1664-1671 (2013).

93. Miyauchi T, Wei EP, Povlishock JT. Evidence for the therapeutic efficacy of either mild hypothermia or oxygen radical scavengers after repetitive mild traumatic brain injury. J. Neurotrauma 31(8), 773-781 (2014).

94. Xuan W, Vatansever F, Huang L et al. Transcranial low-level laser therapy improves neurological performance in traumatic brain injury in mice: effect of treatment repetition regimen. PLoS ONE 8(1), e53454 (2013). 
